\title{
Essentials in the Training of University Librarians-III
}

Dr. Williamson is director of libraries and dean of the School of Library Service, Columbia University.

$\hat{L}^{\mathrm{T}}$

Columbia we seem not to have developed a definite philosophy for the training of university librarians-an important part of our program. Perhaps it would be more accurate to say that we have never attempted to formulate in a definite way a statement of the underlying policies which we follow in our program for the college and university library service. We seem to have gone on the assumption that this field is not so essentially different from others that it needs a special philosophy.

As the term "university librarians" is used, the discussion should perhaps be confined to the part which a professional school can play in the preparation of the chief administrative officer of a university library. That is of course a problem of large enough dimensions to stand by itself, and yet I cannot easily think of that problem apart from training for the entire professional staff of the university library. To my mind the idea of specific training for the head of a university library is somewhat analogous to planned training for the university president. It is a fairly simple exercise to set down the main requirements in the way of education, experience and special abilities required either for the president or the librarian of a university, but it is not much easier to produce a successful chief librarian for a large university by any course of training than it would be to turn out university presidents by applying some formula to whatever raw material offered itself for the purpose.

This thought leads, then, to the first and perhaps the most important tenet in my personal philosophy of training for the university librarian, namely, that emphasis should be laid by the library schools and by all concerned on thorough training for the entire professional staff. For some years it has seemed that there is a serious dearth of men and women well qualified to assume the responsibilities of chief librarian. This, in my opinion, does not necessarily indicate a need for more attention to library school training for such positions, but rather to the need of (I) bringing into university library work people of a higher level of ability with a better and different kind of general education, (2) thorough professional training for the entire professional staff, and (3) more opportunity for intensive experience in positions of some responsibility in various departments of the library.

\section{Advises Training on the Job}

I want to lay special emphasis on the importance of giving an opportunity to men and women who show some capacity for administrative work to gain a broad back- 
ground of experience. It seems to me that it is the lack of such opportunities at present rather than inadequate library school training that makes it so difficult to find material for the chief administrative positions. I have no doubt that among the younger members of the professional staff of every university library are persons who, if given an opportunity to supplement their library school training by thorough practical experience in every aspect of the library's work, would make as good or better university librarians than those who now hold the positions. Not a great deal can be done through extending or improving the library school curriculum. Much can be done, on the other hand, by laying down and vigorously following a rational plan for the practical training on the job of the library school graduate who shows any capacity for leadership.

This statement is likely, I fear, to seem less like a philosophy of training than an elaborate alibi for the library schools. Having tried above to shift much responsibility from the professional school to the university libraries themselves, I now go back to register a complaint about the material with which the schools have to work. It is all very well for the library schools to make an effort to admit only those who are superior in personal and educational equipment. At Columbia we think we are pretty successful in weeding out mediocre applicants, but even the superior college graduates lack much of the basic knowledge and training necessary for successful work in the college and university library field. Professor Fay, of the Columbia faculty, tells me that nearly 100 per cent of her students come from college with little or no knowledge of the literature or bibliographical sources of any subject, and that this is just as true of those who have Master's and Doctor's degrees as of those who have only a Bachelor's degree. Even in the fields in which the holders of higher degrees have specialized, their knowledge of the literature and bibliography of their subject is quite inadequate. The library school must therefore do what it can to supplement a deficient college training. But fundamental training for university librarianship will be inadequate until students come to the library schools with some knowledge of the bibliography and literature of the subjects they have studied in college. If this is too much to expect from college and university faculties, then perhaps the library schools will have to assume full responsibility and add another year or two to the one year now generally given to the fundamental training.

\section{Special Difficulties}

May I return for a moment to the problem of weeding out the mediocre applicant for admission? It has seemed to me that at this point the library school has two special difficulties not encountered, at least to the same degree, by professional schools in other fields. And these special difficulties relate rather more specifically to students aiming to enter college and university work than other types of library service. The first difficulty arises because for so many of the applicants the main reason for a library career lies in the fact that they had to work their way through college and found that an appointment as student assistant in the library offered the advantages of a flexible schedule, pleasant and socially respectable employment, and a dependable if not munificent income. Pressure is sometimes put on the librarian to employ needy students without regard 
to their ability or aptitude for the work. Indeed in some institutions scholarship aid automatically takes the form of a student assistantship in the library, the librarian not even being consulted. The work being of predominantly routine character puts a premium on patience, regularity, and a certain kind of dependability, rather than on imagination, initiative, and the higher levels of ability. The type of student assistant who sticks to the job and earns the commendation of his superiors easily persuades himself that he is cut out to be a librarian. At all events, that is the line of least resistance for the mediocre student assistant and the stage is all set to make it easy for him to get into the library school after he graduates.

\section{A Surprising Attitude}

Responsible library authorities in their recommendations unconsciously overrate a certain type of student assistant of mediocre ability. Deans and professors, knowing that the student was able to hold his job in the library, and not being too sure that he would succeed at anything else, lend a willing hand to get him accepted by the library school, with a scholarship if possible. Though no one would think of him as a good prospect for law or medicine or engineering, all are willing to agree that he will make a good librarian! It is surprising how often this attitude on the part of college officers and teachers is met with in handling applications for admission. Sometimes they say quite frankly that the applicant is too good for library work. Often they rate him average or less in general, but exceptional for library work, obviously assuming that less is required for librarianship than for other professions.

Having pointed out what I have come to look upon as a serious problem in the recruiting of library school students who wish to go into university library work, I must hasten to add that I do not mean to classify all students who have to work their way through college as mediocre, though I think the student who is entirely selfdependent suffers a serious handicap in getting the kind of education he needs to make a successful career in university library work. Though I suspect that the ratio of mediocrity is high among student assistants who are tempted to go on to library school, I must add that some of our ablest students-the men and women who are certain to go -to the top-would have been lost to us if they had not discovered the library profession through accidental employment as student assistant in their college library.

This leads us, then, to one final observation: that in training for university librarianship the library schools are dependent in a peculiar way on the responsible members of college and university library staffs for aid in selecting for admission the right kind of student material. You have a heavy responsibility for the kind of students you send us, as well as for practical training on the job after we have done the best we can for them in one or at most two years of professional training. 